\title{
Performances of dairy cows grazing on alpine pasture under a Leaders-Followers system
}

\author{
P Berzaghi, I Andrighetto, G Cozzi
}

Department of Animal Science, University of Padua, Italy

\begin{abstract}
At the beginning of the grazing season it is usual to observe, in the mountain regions, a severe drop in milk yield in high producing cows (Andrighetto and Ramanzin, 1987, Zoot Nutr Anim, 13, 119). The present study aims to evaluate in an alpine pasture the LeadersFollowers grazing system (LF) as a management tool to limit this decrease in production.
\end{abstract}

The study was carried out in a commercial farm located in the north-west area of the Italian Alps on an elevation of $1000 \mathrm{~m}$ above the sea level. The pasture (23.5 ha), divided into four paddocks, was composed of more than 30 species, mainly grasses (Festuca rubra, Poa pratensis and trivialis) and weeds (Deschampsia caespitosa). The milking herd (36 Brown Swiss cows) was divided into two groups (Control and LF) balanced for the milk yield recorded before the beginning of the grazing season. Each group was allowed to graze half of each paddock divided by electric fences. The LF group grazed the assigned areas under a Leaders-Followers system dividing the animals between Leaders and
Followers according to milk produced. During milking all animals received a commercial supplement (CP : $18.6 \%$ DM ; NDF : $16.1 \%$ DM ; UFL :1.02 /kg DM). Daily milk yield was recorded at wk 4 and 8 of the grazing trial and herbage and milk samples were collected for composition analysis.

Although Leaders had the opportunity to graze each paddock first, the advantage in terms of herbage quality was low and the forage available to the LF and Control had similar composition. Under the Leaders-Followers grazing system high producing animals were able to maintain a milk yield above $20 \mathrm{~kg} / \mathrm{d}$ but with a decrease due to grazing, similarly to lower producing animals. However, as indicated by the results of milk persistency, on average, the reduction in milk yield for LF was greater than Control cows.

In conclusion, in alpine pastures, the LeaderFollowers grazing system is able to sustain milk yield of the more productive animals but it does not offer any advantage compared to the conventional rotational grazing

\begin{tabular}{lccccc} 
& Leaders & Followers & Avg LF & Control & Significance \\
\hline $\begin{array}{l}\text { Herbage composition } \\
\quad \text { CP }\end{array}$ & 13.4 & 12.1 & 12.8 & 12.2 & NS \\
$\quad$ NDF & 63.5 & 66.1 & 64.8 & 64.4 & NS \\
$\begin{array}{l}\text { Milk production }(\mathrm{kg} / \mathrm{d}) \\
\quad \text { before grazing }\end{array}$ & 27.3 & 17.4 & 22.4 & 22.6 & NS \\
$\quad$ grazing & 23.0 & 12.9 & 18.0 & 19.0 & NS \\
$\begin{array}{l}\text { Persistency (\%) } \\
\text { Milk composition (\%) }\end{array}$ & 84.0 & 72.4 & 78.2 & 83.4 & NS \\
$\quad$ fat & 3.6 & 3.7 & 3.7 & 3.7 & NS \\
$\quad$ protein & 3.4 & 3.7 & 3.6 & 3.5 & NS \\
\hline
\end{tabular}

1 Leaders and Followers vs Control 